\title{
Rootless calc-silicate folds in granite: An implication towards syn- to post-plutonic emplacement
}

\author{
Aditya U Joshi and Manoj A Limaye* \\ Department of Geology, Faculty of Science, The Maharaja Sayajirao University of Baroda, \\ Vadodara 390 002, India. \\ *Corresponding author.e-mail: limaye.manoj-geology@msubaroda.ac.in
}

MS received 5 May 2017; revised 19 September 2017; accepted 14 November 2017; published online 26 June 2018

Deformation of the Champaner Group of rocks that form a part of Southern Aravalli Mountain Belt, western India, occurred during the Grenville orogeny (ca. 1400-935 Ma). Two phases of deformation are recorded: $\mathrm{D}_{1}$, persistent throughout the group and characterised by westerly plunging tight isoclinal folds and $\mathrm{D}_{2}$, a localized phase of deformation associated with shortening of the earlier folds from the eastern margin. Both the phases of deformation are in association with the syn-tectonically emplaced Godhra granite. The present work records rootless calc-silicate folds in granite belonging to the older formation, located at the eastern fringe of the Champaner Group. Field evidences suggest superimposition of Type 2 interference pattern trending NE-SW over rootless Type 0 of varying trends from NW-SE to N-S. The superposed pattern obtained from the field study differs in terms of structural trends with the neighbouring Precambrian stratigraphic units. These stratigraphic units include the Champaner Group to which the study area belongs, the Kadana Formation of the Lunavada Group and Pre-Chamapaner Gneissic Complex. Rootless character of folds found within the study area imply syn-post plutonic emplacement of Godhra granite.

Keywords. Grenville orogeny; Champaner Group; Southern Aravalli Mountain Belt; deformation; rootless folds; Godhra granite.

\section{Introduction}

The Champaner Group forms the youngest group in the Aravalli Supergroup, located at the eastern fringe of Gujarat and it occupies entirely the Shivrajpur, Jambughoda and Bodeli region (Gupta et al. 1992, 1995, 1997). The Champaner Group forms the part of southernmost extension of the Southern Aravalli Mountain Belt (SAMB) in Gujarat and is located at the junction between the two older sequences, viz., the Lunavada Group in the north and pre-Champaner rocks in the southeast direction. Rocks of the SAMB displays significant variation of the structural trend from NE-SW to E-W in Gujarat and continues to exhibit NW-SE trend in the older Pre-Champaner rocks extending right up to parts of Jhabua district of Madhya Pradesh (figure 1a).

The Champaner Group is intruded by younger plutonic rocks, i.e., Godhra granite to the northern, eastern and the southern margins, whereas obliterated by the cover of thick Deccan volcanic rocks and recent sediments along the western margin (figure 1b). Numerous available dates on age of 


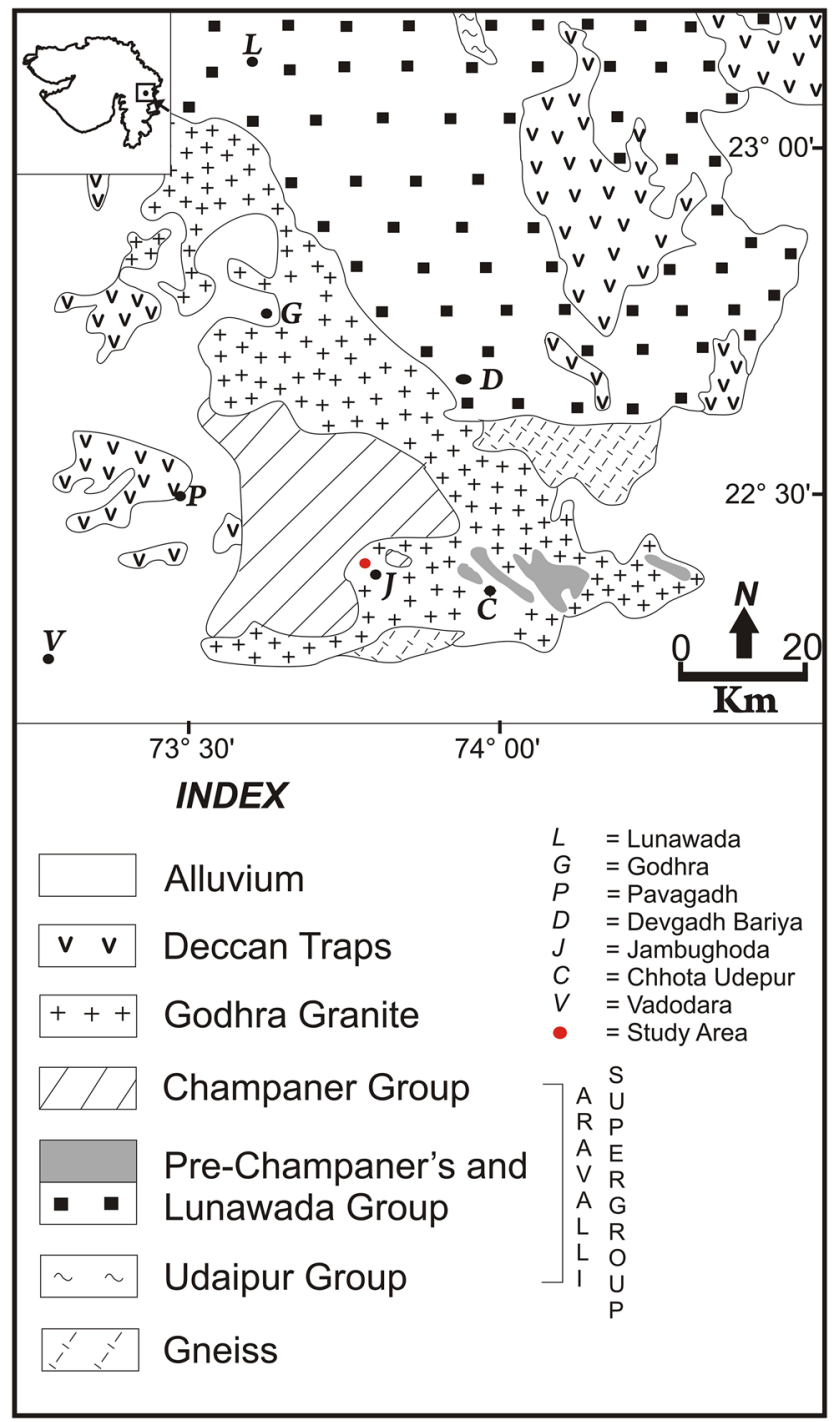

Figure 1(a). Lithostratigraphic map of Southern Aravalli Mountain Belt, NW, India (modified after Mamtani and Greiling 2005).

Godhra granite have a time range of 1168-938 Ma suggesting prolonged emplacement period $(\mathrm{Rb} / \mathrm{Sr}$ method $1168 \pm 30$ Ma: Srimal and Das 1998; SmNd method $1050 \pm 50$ Ma: Shivkumar et al. 1993; Rb-Sr method $965 \pm 40$ Ma: Goyal et al. 2001; Rb-Sr method $955 \pm 20$ Ma Gopalan et al. 1979; Rb-Sr method 950 Ma, Crawford 1975; Rb-Sr method: $938.8 \pm 20$ Ma: Srimal and Das 1998). Lithologically, the Champaner Group consists of a sequence of meta-subgreywacke, sandy phyllite, graphite-schist, quartzite, polymictic metaconglomerate, dolomitic limestone and manganiferous phyllite (Gupta et al. 1980, 1997). The grade of regional metamorphism has reached up to greenschist facies condition, which is implied by the development of chlorite, muscovite and biotite, whereas hornblende hornfels facies characterise the contact metamorphic condition giving rise to the development of pelitic hornfels and skarns (Jambusaria and Merh 1967; Das et al. 2009).

Structurally, the entire sequence depict simple deformation pattern as compared to the Aravalli and Delhi Supergroup. The rocks of the Champaner Group have undergone two phases of deformation, viz., $\mathrm{D}_{1}$ and $\mathrm{D}_{2} . \mathrm{D}_{1}$ deformation dominates throughout the group which led to the development of open-to-tight isoclinal folds with axial traces trending in a WNW-ESE to E-W direction. $\mathrm{D}_{2}$, a localized phase of deformation associated with shortening of the earlier folds from the eastern margin of the Champaner Group signifying broad open folds with $\mathrm{N}-\mathrm{S}$ striking axial traces developed on regional limbs of $\mathrm{D}_{1}$ folds (Jambusaria and Merh 1967; Gopinath et al. 1977; Srikarni and Das 1996; Gupta et al. 1997; Karanth and Das 2000; Mamtani and Greiling 2005; Joshi and Limaye 2014; Patel et al. 2016). There also exist signatures of $\mathrm{D}_{1}$ axial planar strike slip faults and shear zones across the Champaner Group (Joshi et al. 2018). Due to the heterogeneity in terms of manganiferous beds and structure, a suggestion has been made that the Champaner Group be described as a sequence younger to both Aravalli and Delhi Supergroup (Roy 1988).

The paper focuses on field evidences of isolated and deformed calc-silicate band of Khandia Formation of the Champaner Group, occur as enclaves within younger granite. The present study will be helpful to understand the effects of prolong emplacement period of Godhra granite in the region and will be helpful to resolve the stratigraphic debate pertaining to the structure of the Champaner Group of rocks. The study area is inand-around Jothwad village, located at the eastern fringe of the Champaner Group. Detailed structural mapping has been carried out in the terrain. Structural attributes acquired from the field work have been plotted on stereographic projection to interpret the fold pattern. The inferences derived from (i) the field evidences; (ii) the existing Anisotropy of Magnetic Susceptibility (AMS) data from Godhra granite, and (iii) the existing subsurface shallow seismic profiling using cost effective Microtremor technique are used to explain the syn-post plutonic emplacement with $\mathrm{D}_{1}$ deformation of the Champaner Group of rocks. 


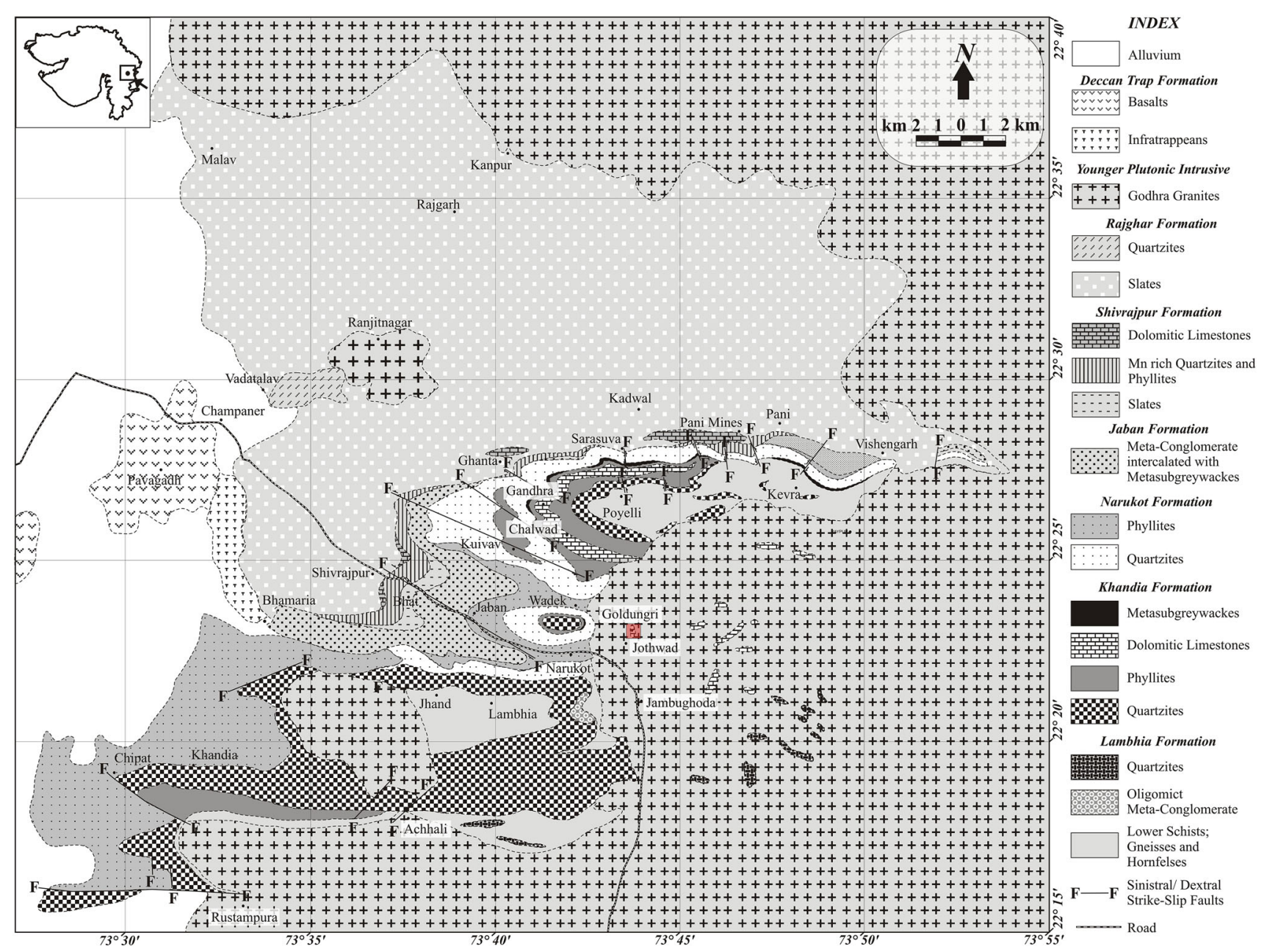

Figure 1(b). Generalized geological map of the Champaner Group and neighbouring areas (modified after Jambusaria and Merh 1967 and Gupta et al. 1997). Filled red square indicates the study area.

\section{Geological and structural set-up of the study area}

The study area is the part of Khandia Formation of the Champaner Group, Aravalli Supergroup. The Khandia Formation is considered to be the second oldest formation of the Champaner Group (table 1), primarily composed of phyllite, quartzite, dolomitic limestone and metasubgreywackes (Gupta et al. 1997). However, the area under investigation consists of calc-silicate rock of Meso-Proterozoic age enveloped by younger plutonic intrusive, i.e., Jambughoda granite (Goyal et al. 1997). Jambughoda granite is the part of Godhra granite, emplaced along a major NW-SE Precambrian trend (Mamtani and Greiling 2005; Joshi et al. 2018).

As shown in the geological map of the Jothwad region, the deformed calc-silicate rock is at the centre followed by a thin rim of granite having enclaves of calc-silicate rock, which further grades into massive, medium to coarse grained, leucocratic granite (figures 2, 3a). The calc-silicate rock is greenish grey in colour, fine to coarse grained and massive in nature. At places, the calc-silicate exhibit caught up folded fragments embedded in granite (figure 3b). The intrusive contact between calc-silicate rock and granite can be appreciated along the excavated pit located in vicinity of the study area. The side face of $5 \mathrm{~m}$ deep pit was studied in order to examine the subsurface extent of calc-silicate rock (figure 3c). Minerals that can be identified in the hand specimen include wollastonite, actinolite, piedmontite and winchite, forming typical skarn rock mineralogy (Das et al. 2009).

Structurally, rocks of the study area are poly-deformed and exhibit two sets of fold, viz., $\mathrm{F}_{1}$ 
Table 1. Proterozoic stratigraphic succession of Gujarat and south Rajasthan (after Gupta et al. 1980, 1992).

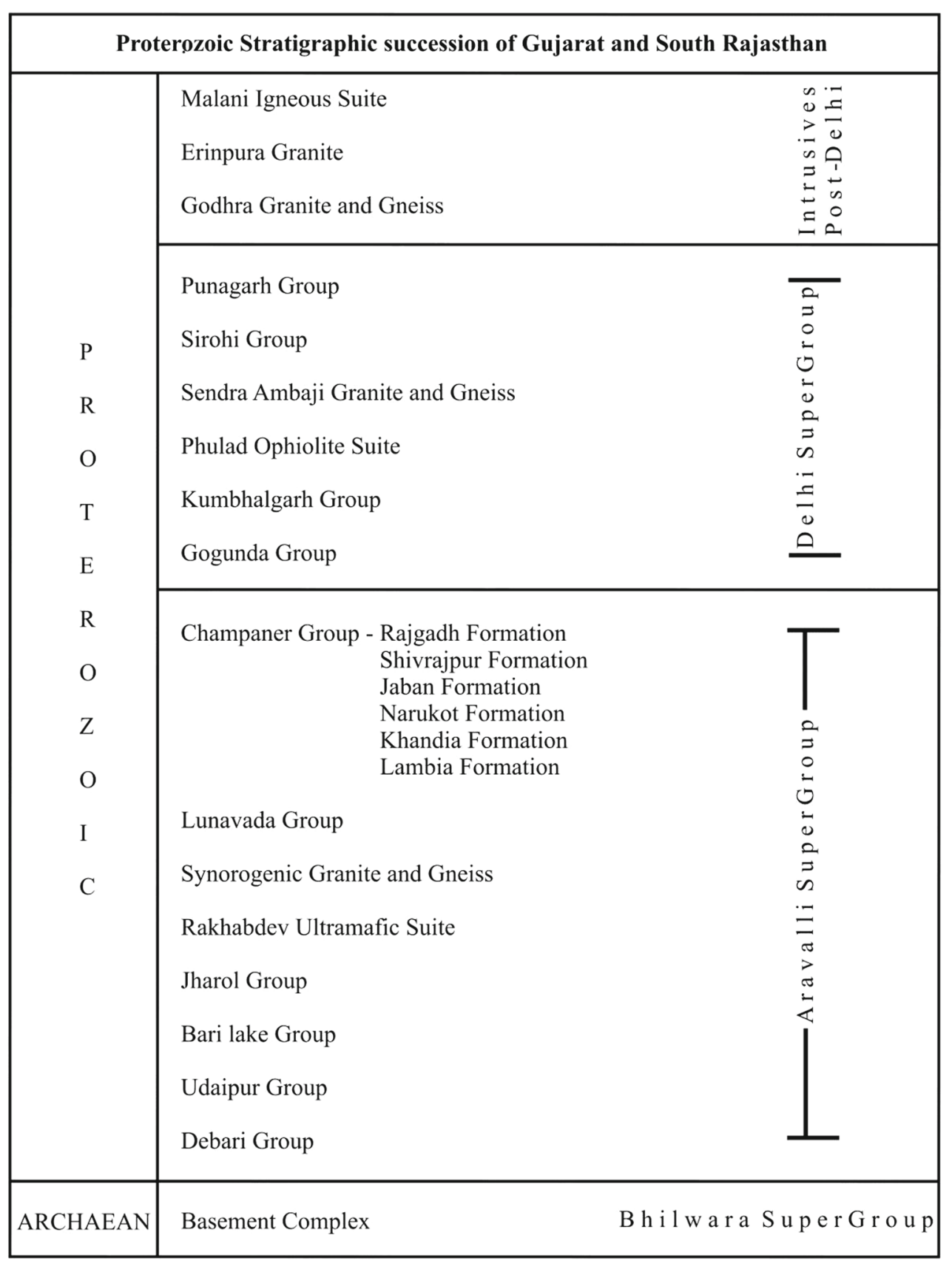

and $\mathrm{F}_{2}$. The northwestern and the southern parts of the study area depict mesoscopic rootless tight/ isoclinal $\mathrm{F}_{1}$ folds (figure $3 \mathrm{~d}$, e). The axial plane in the northwestern part strike NW-SE and fold axes plunges in the direction of $\mathrm{N} 120^{\circ}$ with an amount of $50^{\circ}$, whereas in the southern part of the study area, trend of the axial plane is $\mathrm{N}-\mathrm{S}$ and fold axes plunges due $\mathrm{N}$ with an amount of $52^{\circ}$. By plotting poles of $\mathrm{S}_{1}$ foliation collected from the entire study area, $F_{2}$ axial trace has been projected by using lower hemisphere stereographic projection (figure $3 \mathrm{f}$ ). $\mathrm{F}_{2}$ fold is broad open type synformal structure trending NE-SW and fold axes plunges in the direction of $\mathrm{N}^{\circ} 0^{\circ}$ with an amount of $62^{\circ}$. The superimposition of $F_{1}$ and $\mathrm{F}_{2}$ folds has resulted in development of Type 2 interference pattern over Type 0 (i.e., non-plane non-cylindrical fold over plane cylindrical folds). 


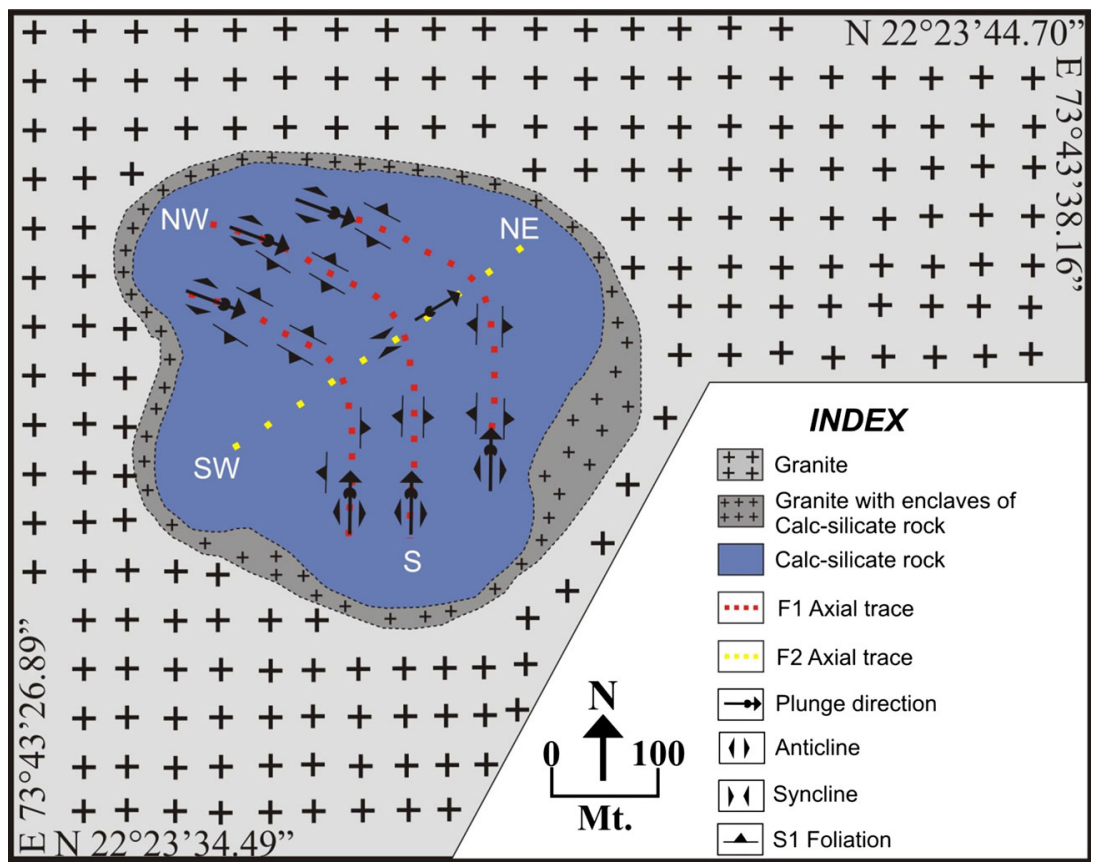

Figure 2. Geological map of the Jothwad region (study area).

The outcrop pattern due to Type 2 interference has resulted in mushroom shaped geometry (figure $3 \mathrm{~g})$.

\section{Discussion and conclusion}

Based on the field evidences of the Jothwad region (figure $3 \mathrm{a}-\mathrm{e}$ ), the folds are rootless and depict no continuity in the subsurface; moreover, they also occur as enclaves in the granite. Therefore, it is suggested that the folding in the study area was prior to the emplacement of the plutonic body. The existing structural set-up adjacent to the study area depict variation in the structural trend, i.e., the Champaner metasediments at the west are characterized by two phases of deformation $\mathrm{D}_{1} \sim$ $\mathrm{E}-\mathrm{W}$ to ESE-WNW and $\mathrm{D}_{2} \sim \mathrm{N}-\mathrm{S}$ and the PreChampaner rocks located at the SE, which consists four phases of deformation from $\mathrm{D}_{1}$ to $\mathrm{D}_{4}$. $\mathrm{D}_{1}$ is characterized by rootless recline folds of $\mathrm{N}-\mathrm{S}$ trend, where as $\mathrm{D}_{2}$ and $\mathrm{D}_{3}$ show $\mathrm{E}-\mathrm{W}$ trend with varied fold morphologies. Finally, $\mathrm{D}_{4}$ depict $\mathrm{N}-\mathrm{S}$ trending warps and kinks. However, last two phases of deformation of Pre-Champaner rocks are pronounced over the Champaner metasediments (Karanth and Das 2000; Das 2003).

The existing structural set-up of the Jothwad region is not only in contrast with the adjacent
Champaner and Pre-Champaner rocks, but also differ from the regional structural set-up of the Southern Aravalli Mountain Belt (SAMB), which includes: (1) The Banded Gneisses at the northeast, (2) the Lunavada Group extended till south of Devgadh Bariya in the north, (3) Pre-Champaner Gneisses at the southeast, (4) the detached Champaner metasedimentary sequence in the west, and (5) Godhra granite in which the study area is located (figure 1a).

Table 2 shows a summary of deformation events recorded in the neighbouring Precambrian stratigraphic units and its relation with the study area. The inferences derived from existing Anisotropy of Magnetic Susceptibility (AMS) data and preferred orientation of feldspar laths from Godhra granite suggest that the range of magnetic foliation in granite strike WNW to WSW and preferred orientation of feldspar laths within granite trends WNW to W (Mamtani and Greiling 2005; Mamtani et al. 2002; Sen and Mamtani 2006). The prevailing structural trends, which are correlatable with synchronous Godhra granitic emplacement are: (1) $\mathrm{D}_{3}$ structures in the Banded Gneisses, (2) $\mathrm{D}_{3}$ structures in the Lunavada Group of rocks, (3) $\mathrm{D}_{2}$ and $\mathrm{D}_{3}$ structures in the Pre-Champaner Gneisses with different fold morphology (a. Recline and b. Upright), and (4) $\mathrm{D}_{1}$ structures in the Champaner Group of rocks. Though the AMS data from 


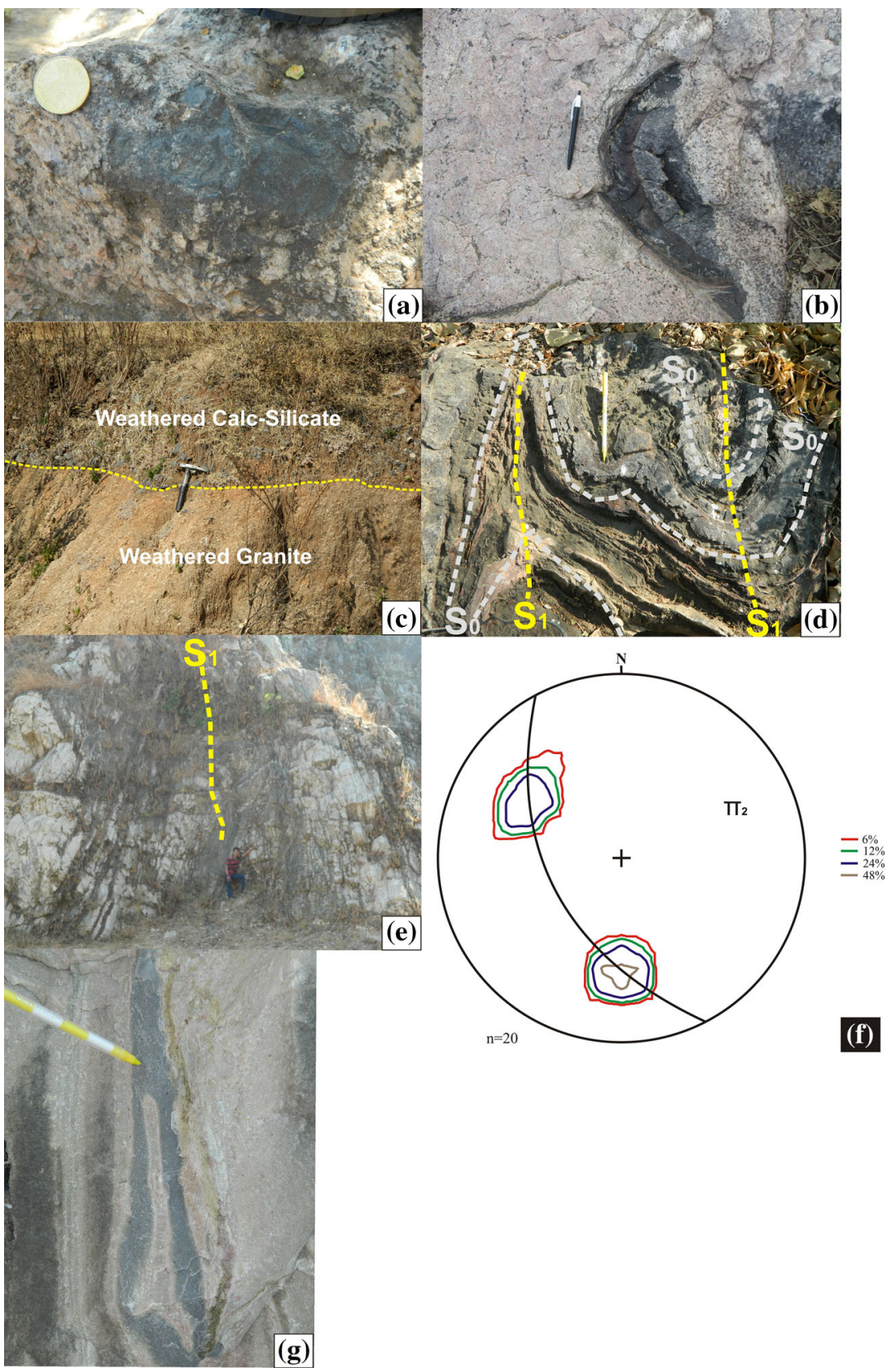

Figure 3. (a) Enclaves of calc-silicate rock in granite (camera faces in eastern direction); (b) Caught up folded fragment of calc-silicate rock embedded in granite (camera faces in southeastern direction); (c) Dotted line demarcates inferred contact between weathered calc-silicate rock and granite at the side face of $5 \mathrm{~m}$ deep pit, in vicinity of the study area (camera faces in western direction); (d) Tight to isoclinal folds in calc-silicate rock in the NW part of the study area (camera faces in southeastern direction); (e) Tight to isoclinal folds in calc-silicate rock in the south part of the study area (camera faces in southern direction); (f) Lower hemisphere stereographic projection of the structural data related to $\mathrm{F}_{2}$ folds, collected from the Jothwad region. Plotting of poles of $S_{1}$ foliation collected from the entire study area. Note that the $F_{2}$ fold axes $\left(\pi_{I I}\right)$ perpendicular to common great circle plunge towards the NE direction; (g) Mushroom-shaped outcrop geometry on account of Type 2 interference (camera faces in northeastern direction).

Godhra granite is found to be concomitant with neighbouring Precambrian stratigraphic units, it is unmatched with the trends recorded within the study area.
Wide range of dates on age of Godhra granite as mentioned in section (1) indicate longer time span of emplacement, i.e., from 1.1 to $0.93 \mathrm{Ga}$. However, the deformation date for the Champaner 


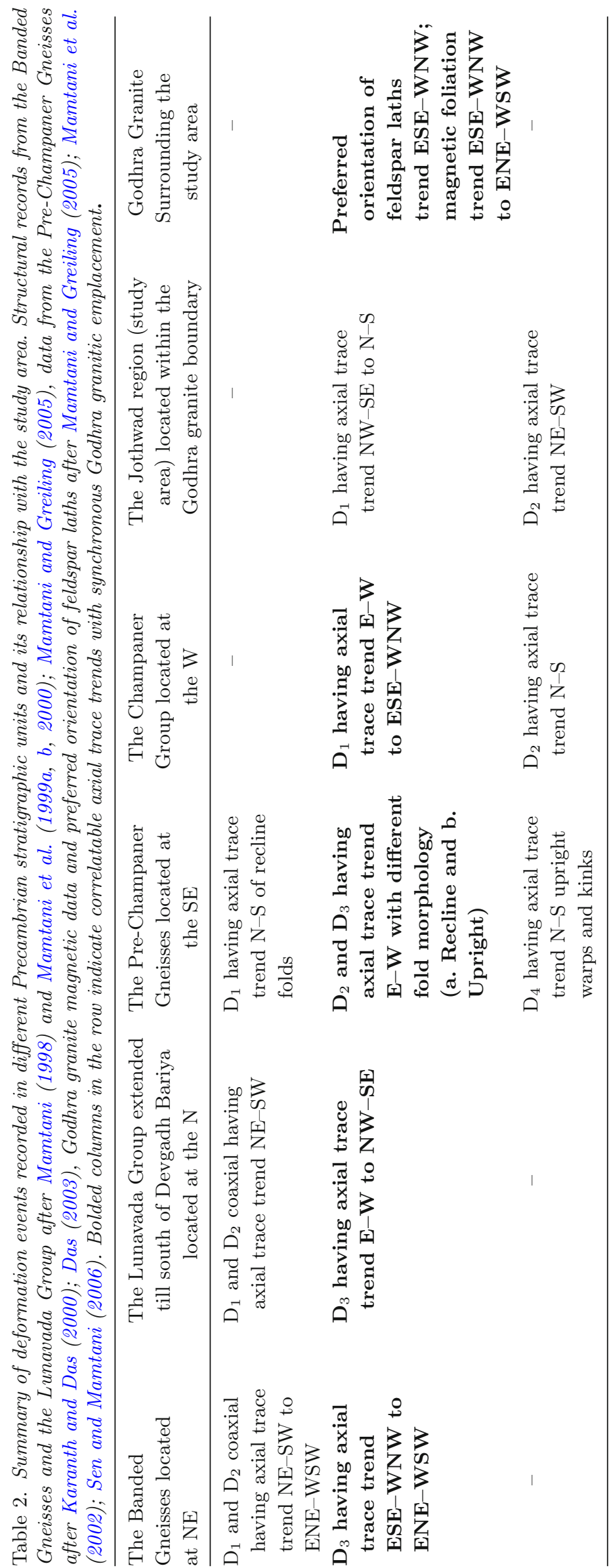


metasediment is still undetermined. Northern extremity of Godhra granite is marked by the contact with the Lunavada Group of rocks. The field evidence for granite and related pegmatites intruding foliation in schists of Kadana Formation, Lunavada Group, indicates that the intrusion continued even after $\mathrm{D}_{3}$ deformation of the Lunavada region. Microstructural records specify advent of thermal event related to late $\mathrm{D}_{3} /$ post- $\mathrm{D}_{3}$ Godhra granitic intrusion in the Lunavada terrain (Mamtani and Karanth 1996; Mamtani et al. 2001). Based on which, a possibility can be determined that $\mathrm{D}_{3}$ deformation of the Lunavada region and $\mathrm{D}_{1}$ deformation of the Champaner region were coeval events (Mamtani and Greiling 2005). The above inference also deflates the suggestion given by Roy (1988) to reorder the stratigraphic position of the Champaner Group over Delhi Supergroup.

Microtremor measurements carried out at 32 sites along $\mathrm{D}_{1}$ axial trace of Narukot Dome and its western extension by Joshi et al. (2018) is helpful to identify two distinct rheological boundaries based on frequency ranges determined in the terrain. These rheological boundaries include (i) the juxtaposed Champaner metasediment over granite (C-Gr) boundary and (ii) intercalated phyllite and quartzite (P-Qr) boundary. Out of which, (i) CGr boundary lies in vicinity of the study area at station 31 . The inferences derived by the subsurface shallow seismic profiling using microtremor technique indicate that the sporadic granitic plutons emplaced in the terrain have uprooted the Champaner metasediments giving 'rootless' characteristic in the study area and at the Narukot dome as well as to its western extension.

All above evidences lead to the conclusion that even after the $\mathrm{D}_{1}$ deformation of the Champaner Group of rocks, the Godhra granitic emplacement continued to give rise rootless folds along with caught up fragments in the granitic mass of the Jothwad region. This prolonged emplacement also probably uprooted the Champaner metasediments exposed in the western part of the study area.

\section{Acknowledgements}

Aditya U Joshi is thankful for DST PURSE Programme for providing the fellowship. AUJ and MAL are grateful to Prof. L S Chamyal (Head, Department of Geology, The M.S. University of Baroda) for providing necessary facilities. Technical discussion with Prof. D A Sant (MSUB) is duly acknowledged. Authors are grateful to
Dr S Mukherjee (IITB) for giving valuable suggestions. We express our deep gratitude to the Editor-in-Chief, Prof. N V Chalapathi Rao and Prof. Saibal Gupta (Corresponding Editor). The review comments by Prof. Manish A Mamtani (IITKGP) and anonymous reviewer helped us to improve the quality of the paper.

\section{References}

Crawford A R 1975 Rb-Sr age determination for the Mount Abu granite and related rocks of Gujarat; J. Geol. Soc. India 16 20-28.

Das S 2003 Deformation and metamorphic history of the Precambrian rocks in northeastern part of Vadodara district, Gujarat with a reference to the stratigraphy and tectonics; Unpbl. Ph.D. thesis, The M.S. University of Baroda, Vadodara, 110p.

Das S, Singh P K and Sikarni C 2009 A preliminary study of thermal metamorphism in the Champaner Group of rocks in Panchmahals and Vadodara districts of Gujarat; Indian J. Geosci. 63 373-382.

Gopalan K, Trivedi J R, Merh S S, Patel P P and Patel S G $1979 \mathrm{Rb}-\mathrm{Sr}$ age of Godhra and related granites, Gujarat; Proc. Indian Acad. Sci. 88A 7-17.

Gopinath K, Rao A D P and Agrawal G G et al. 1977 Precambrians of Baroda and Panchmahals districts: Elucidation of stratigraphy and structure; Rec. Geol. Surv. India 73 1-52.

Goyal N, Pant P C, Hansda P K and Pandey B K 2001 Geochemistry and $\mathrm{Rb}-\mathrm{Sr}$ age of the Late Proterozoic Godhra Granite of Central Gujarat, India; J. Geol. Soc. India 58 391-398.

Goyal N, Varughese S K, Hansda P K, Ramachandran S and Singh R 1997 Geochemistry of Granites of Jambughoda, Panchmahals District, Gujarat and Uranium Mineralization in Champaner Group; J. Geol. Soc. India 50 769-778.

Gupta S N and Arora Y K et al. 1980 Lithostratigraphic map of Aravalli Region, southern Rajasthan and northeastern Gujarat; Geol. Surv. India Publ., Hyderabad.

Gupta S N and Arora Y K et al. 1995 Geological Map of the Precambrians of the Aravalli Region, southern Rajasthan and northeastern Gujarat, Geol. Surv. India Publ., Hyderabad.

Gupta S N, Arora Y K, Mathur R K et al. 1997 The Precambrian Geology of the Aravalli region, southern Rajasthan and NE Gujarat; Geol. Surv. India Memoir 123 1-262.

Gupta S N, Mathur R K and Arora Y K 1992 Lithostratigraphy of Proterozoic rocks of Rajasthan and Gujarat - a review; Rec. Geol. Surv. India 115 63-85.

Jambusaria B B and Merh S S 1967 Deformed greywacke conglomerates of Jaban near Shivrajpur, Panchmahals district, Gujarat; Indian Miner. 8 6-10.

Joshi A U and Limaye M A 2014 Evidence of syndeformational granitoid emplacement within Champaner Group, Gujarat; J. Maharaja Sayajirao Uni. Baroda 49 45-54.

Joshi A U and Sant D A et al. 2018 Sub-surface profiling of granite pluton using Microtremor method: southern Aravalli, Gujarat, India; Int. J. Earth Sci. 107 191-201. 
Karanth R V and Das S 2000 Deformational history of the Pre-Champaner gneissic complex in Chhota Udepur area, Vadodara district, Gujarat; Indian J. Geol. 72 43-54.

Mamtani M A and Greiling R O 2005 Granite emplacement and its relation with regional deformation in the Aravalli Mountain Belt (India) - inferences from magnetic fabric; J. Struct. Geol. 27 2008-2029.

Mamtani M A 1998 Deformational mechanisms of the Lunawada Pre-Cambrian rocks, Panchmahal district, Gujarat; Unpublished Ph.D. thesis, M.S. University of Baroda, India, 268p.

Mamtani M A and Karanth R V 1996 Effect of heat on crystal size distributions of quartz; Curr. Sci. 70 396399.

Mamtani M A and Greiling R O et al. 1999a Orogenic deformation and its relation with AMS fabric - an example from the Southern Aravalli Mountain Belt, India; In: The Indian Subcontinent and Gondwana: A Palaeomagnetic and Rock Magnetic Perspective (eds) Radhakrishna T and Piper J D, Geol. Soc. India Memoir 44 9-24.

Mamtani M A, Karanth R V and Greiling R O 1999b Are crenulation cleavage zones mylonites on the microscale?; J. Struct. Geol. 21 711-718.

Mamtani M A, Karanth R V, Merh S S and Greiling R O 2000 Tectonic evolution of the Southern part of Aravalli Mountain Belt and its environs - possible causes and time constraints; Gondwana Res. 3 175-187.

Mamtani M A, Merh S S, Karanth R V and Greiling R O 2001 Time relationship between metamorphism and deformation in Proterozoic rocks of the Lunawada region, southern Aravalli Mountain Belt (India) - a microstructural study; J. Asian Earth Sci. 19 195205.

Mamtani M A, Karmakar B and Merh S S 2002 Evidence of polyphase deformation in gneissic rocks around Devgadh Bariya: implications for evolution of Godhra Granite in the southern Aravalli region (India); Gondwana Res. 5 401-408.

Patel D, Joshi A U and Limaye M A 2016 Sequential development of microstructures in quartzites of Champaner Group, Gujarat; J. Geol. Res. 1(2) 101-104.

Roy A B 1988 Stratigraphic and tectonic framework of the Aravalli mountain range; In: Precambrian of the Aravalli mountain, Rajasthan, India (ed.) Roy A B, Geol. Soc. India Memoir 7 3-31.

Sen K and Mamtani M A 2006 Magnetic fabric, shape preferred orientation and regional strain in granitic rocks; $J$. Struct. Geol. 28 1870-1882.

Shivkumar K, Maithani P B and Parthasarathy R N et al. 1993 Proterozoic rift in lower Champaners and its bearing in uranium mineralisation in Panchmahals district, Gujarat; Annual Convention of Geological Society of India, Department of Geology, M.S. University of Baroda, Vadodara, India.

Srikarni C and Das S 1996 Stratigraphy and sedimentation history of Champaner Group, Gujarat; J. Indian Assoc. Sed. 15 93-108.

Srimal N and Das S 1998 On the tectonic affinity of the Champaner Group of rocks, eastern Gujarat; International seminar on the Precambrian crustal evolution of central and eastern India. UNESCO-Lugs-IGCP-368, Bhubaneswar, pp. 226-227. 